\title{
DESIGN OF EXPERIMENTS IN TRUCK COMPANY
}

\author{
DOI: 10.12776/QIP.V19I1.419
}

BIBIANA KASELYOVÁ, MICHAL TKÁČ

Received 18 November 2014, Revised 17 February 2014, Accepted 20 April 2015

\begin{abstract}
Purpose: Design of experiment (DOE) represent very powerful tool for process improvement vastly supported by six sigma methodology. This approach is mostly used by large and manufacturing orientated companies. Presented research is focused on use of DOE in truck company, which is medium size and service orientated. Such study has several purposes. Firstly, detailed description of improvement effort based on DOE can be used as a methodological framework for companies similar to researched one. Secondly, it provides example of successfully implemented low cost design of experiment practise. Moreover, performed experiment identifies key factors, which influence the lifetime of truck tyres.

Design/methodology: The research in this paper is based on experiment conducted in Slovakian Truck Company. It provides detailed case study of whole improvement effort, together with problem formulation, design creation and analysis, as well as the results interpretation. The company wants to improve lifetime of the truck tyres. Next to fuel consumption, consumption of tyres and their replacement represent according to them, one of most costly processes in company. Improvement effort was made through the use of PDCA cycle. It start with analysis of current state of tyres consumption. The variability of tyres consumption based on years and types was investigated. Then the causes of tyres replacement were identified and screening DOE was conducted. After a screening design, the full factorial design of experiment was used to identify main drivers of tyres deterioration and breakdowns. Based on result of DOE, the corrective action were propose and implement
\end{abstract}

Findings: Based on performed experiment our research describes process of tyres use and replacement. It defines main reasons for tyre breakdown and identify main drivers which influence truck tyres lifetime. Moreover it formulates corrective action to prolong tyres lifetime. 
Originality: The study represents full description of problem solving procedurefrom problem definition to evaluation of corrective action. It can be also understood as methodological guidelines for similar companies. Moreover it is example of good practise. It shows how to conduct low cost DOE based improvement effort in non-manufacturing company.

Keywords: design of experiments; process improvement; full factorial design; tire tread; screening design; SME

\section{INTRODUCTION}

Organizations try to secure their long-term economic success by continuous improvement of their products, processes and services in order to maximize their wellbeing (Szabo et al., 2013). Success of such improvements is determined by understanding how these elements behave and interact inside and outside of their own system.

Design of Experiments (DOE) is known as statistical method used by scientist and practitioners to better understand complex phenomena. It can be defined as a "systematic, rigorous approach to engineering problem-solving that applies principles and techniques at the data collection stage so as to ensure the generation of valid, defensible, and supportable engineering conclusions" (Firka, 2011). Approach was founded by Sir Roland A. Fisher who used it for agricultural research (Barad, 2014). Its purpose is "to study effects of simultaneous, multiple variable in the most economical way" (Chompu-inwai et al., 2014). Barad (2014) adds, that its economy lies in its ability to obtain reliable results based on relatively small sample (trials). Moreover Johnson and Steele (2012) supply other four advantage to prove effectiveness of this method. They are: 1.efficient capturing of data; 2.complex scope on solving problem; 3.better understanding of interaction between process inputs; 4. evidence based support of decision. DOE also represent a direct replacement of OFAT (one factor at a time) framework as well as Shaninin's sequential testing method (Antony et al., 2011).

Even though number of studies prove usefulness of DOE in manufacturing (see Ilzarbe, 2008), non-manufacturing (see Antony et al., 2011) or even simulation (Kleijnen, 2005) environment, its application in real organizations remain somewhat limited (Tanco et al., 2008; Firka, 2011). However, because of rapid growth of continuous improvement methodology based on Six sigma, organizations are more encourage to use DOE more (Ilzarbe, 2008). On the other hand as recent studies showed DOE is usually use as improvement tool for large organization to their support manufacturing (Ilzarbe, 2008 ; Chompu-inwai et al., 2014) and also non-manufacturing processes (Antony et al., 2011). There is only a limited number of case-studies describing implementation of DOE in SME (Chompu-inwai et al., 2014) or in non-manufacturing areas (Antony et al., 2011). 
That is the reason, why we decided to present case study describing implementation of DOE in SME and also in non-manufacturing area of SME.

\section{METHODOLOGY}

The research in this paper is based on experiment conducted in Slovakian truck company. The experiment was part of process improvement effort executed from 2009 to 2012 on process of tires maintenance. Although mentioned process is only an auxiliary process, it directly influence the company's primary process called the transportation. Moreover, according to management of company, tires expenditure and their replacement represent next to the fuel consumption second most costly process in company. The improvement effort was based on Deming's PDCA cycle. This framework was chosen because company has good experience with it. The initial phase of PDCA known as "Plan" has several steps:

1) Identification of tires deterioration process

2) Definition of strategic framework

3) Analysis of current state of tires consumption (quantification of problem)

4) Identification of causes, which influence the tires deterioration process

5) Execution of screening experiment

6) Design of full factorial experiment.

The "Do" phase of PDCA cycle dealt with realisation of experiment. Concretely, it was $2^{4}$ full factorial experiment conducted from September 2011 to January 2012. The four factors were chosen from previously selected seven factors based on results of previous screening experiment. The route from Košice in Slovakia to Onesti in Ukraine was chosen as experimental one. It took 4 days to pass and was selected because it was long enough $(2000 \mathrm{~km})$ to measure deterioration of tires. The deterioration was measured by tread depth gauge called Vigor 0$25 \mathrm{~mm}$. Its measurement accuracy was $0.01 \mathrm{~mm}$. Measurement were executed at the same place in every tire. It was above tire TWI mark in the first drain of tire tread pattern. Moreover every tire was marked in order to assure that during experiment will be put at the same position and same side of the truck. These precautions enable to measure deterioration of tire as difference between previously measured tread depth and current one. Tires inflation as well as technical condition of the truck were check before every trial. The values of tire inflation used in experiment were carefully chosen, in order to not effect manoeuvrability of truck, and fulfil legislative requests, as well as safety of truck and material. Based on company request, range of tire inflation used in this paper is not exactly the range used in experiment. It was adjusted by multiplication of constant. During the experiment, organization executes 16 rides with same material and approximately same weight in order to gain 32 
measurement (left and right tire) of tires' tread depth. The frequency of rides were determine by the frequency of orders of this specific delivery.

In the "Check" phase of PDCA the analysis of the experiment were conducted. The whole phase was divided into three parts. First part covering identification factors, which significantly (level of significance $\alpha \geq 1 \%$ ) affect deterioration of tires tread. Second part analyse identified factors and level of their influence on researched process. The last part dealt with optimisation and definition of optimal setting for lowest tires tread deterioration. Most of conducted calculations and graphs were created by use of Destra V.10 from Q-Das ltd. Preliminary study was evaluated by Minitab 17.

The last phase known as "Act" dealt with implementation of result from "Check" phase into the practise and formulation of corrective action.

\section{RESEARCH}

As was mentioned before, presented case study describe improvement of tires' maintenance process. Such improvement effort was based on Deming's PDCA cycle. Description of particular phases are presented below.

\subsection{Plan}

The structure of plan phase consists from 6 steps, which were presented in methodology. Regarding the scope of the paper, the first 4 steps will be described only briefly.

The whole improvement start with identification of tires deterioration process, which is briefly described in Figure 1. In the next phase, the strategic framework of whole improvement effort was determined by management of company.

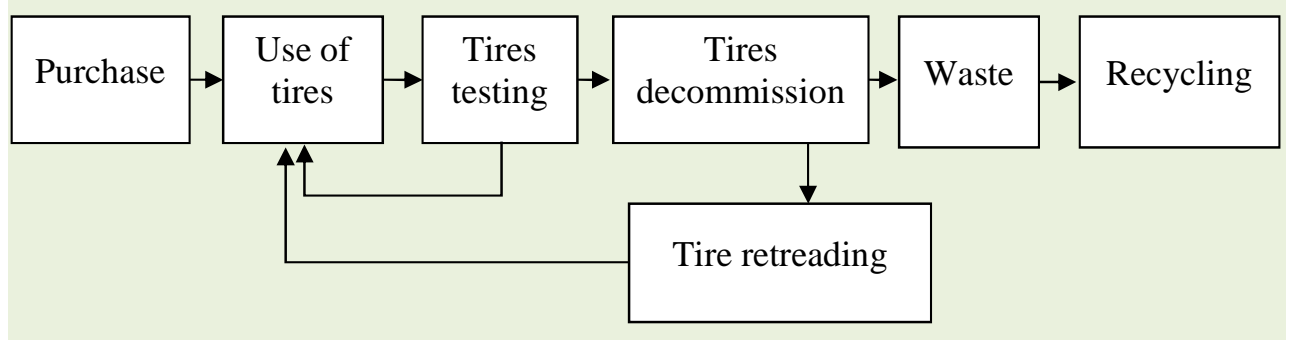

Figure 1 - Tires deterioration process

The strategic framework was used to describe limitations and boundaries of improvement effort. It was pre-determined and represent settings, that could not be changed by improvement action. It include such conditions:

- Conducted improvement actions cannot have negative impact on requirements of stakeholders. 
- Conducted improvement actions cannot have negative effect on fuel consumption.

- Conducted improvement actions cannot have negative effect on truck safety, truck manoeuvrability or it can have negative influence to any other performance parameters of truck.

- The structure of company's truck fleet cannot be changed.

The next step consists of analysis of current state. It represents important stage of plan phase. Aim of the analysis was to estimate potential cost of specified problem and therefore define the suitable budget for its elimination. It starts with review of tires consumption in company. Based on the available accounting documents, the number of tires used during the years 2004 till 2009 was estimated. As further analysis showed consumption of tires became more costly from one year to another. For example in 2006 expenditure regarding tires management constitute in average $4.6 \%$ of yearly truck revenue, on the other hand in 2009 similar expenditures represent in average $9.15 \%$ of yearly truck revenue, which represent almost $100 \%$ increase during the two years. Other part of preliminary analyses consisted of comparing lifetime of tires according to their vendors. The lifetime was measured as a number of kilometres, that truck with this tire went. Although company compared tires from three different producers, according to boxplot analysis presented in Figure 2, the lifetime of tires didn't significantly increase based on change of manufacturer. Because tires with better performance produced by Manufacturer B are about $15 \%$ more expensive than competition, the difference between efficiency of reviewed tires became even narrower.

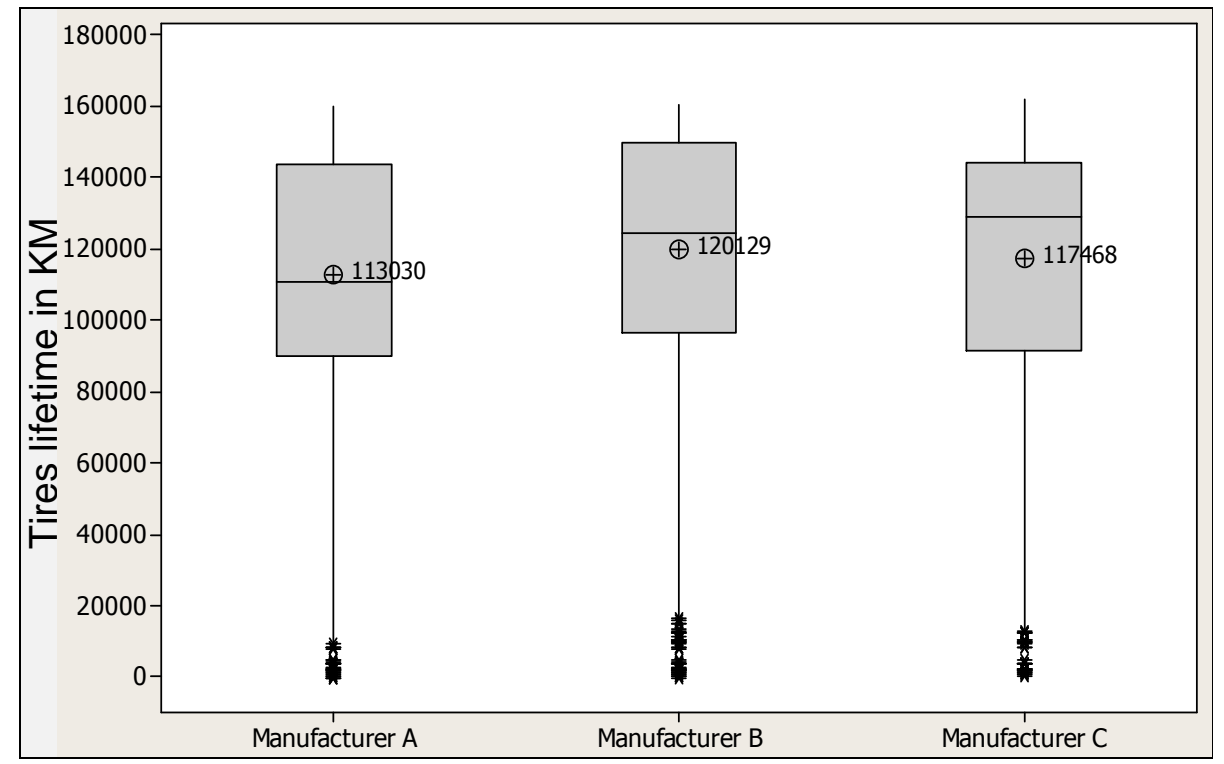

Figure 2 - Analysis of lifetime of tires based on manufacturer 
Plan phase continued with detailed analysis of tires deterioration process. The analysis was conducted to determine causes of tires breakdown. As boxplots showed, lifetime of tires has high variability. The length of tires life time is determined by reasons, which cause their retirement. Based on review of check sheets of 1000 tires, there are 6 main reasons causing end of tire's lifetime. The importance of particular causes were investigate by Pareto analysis.

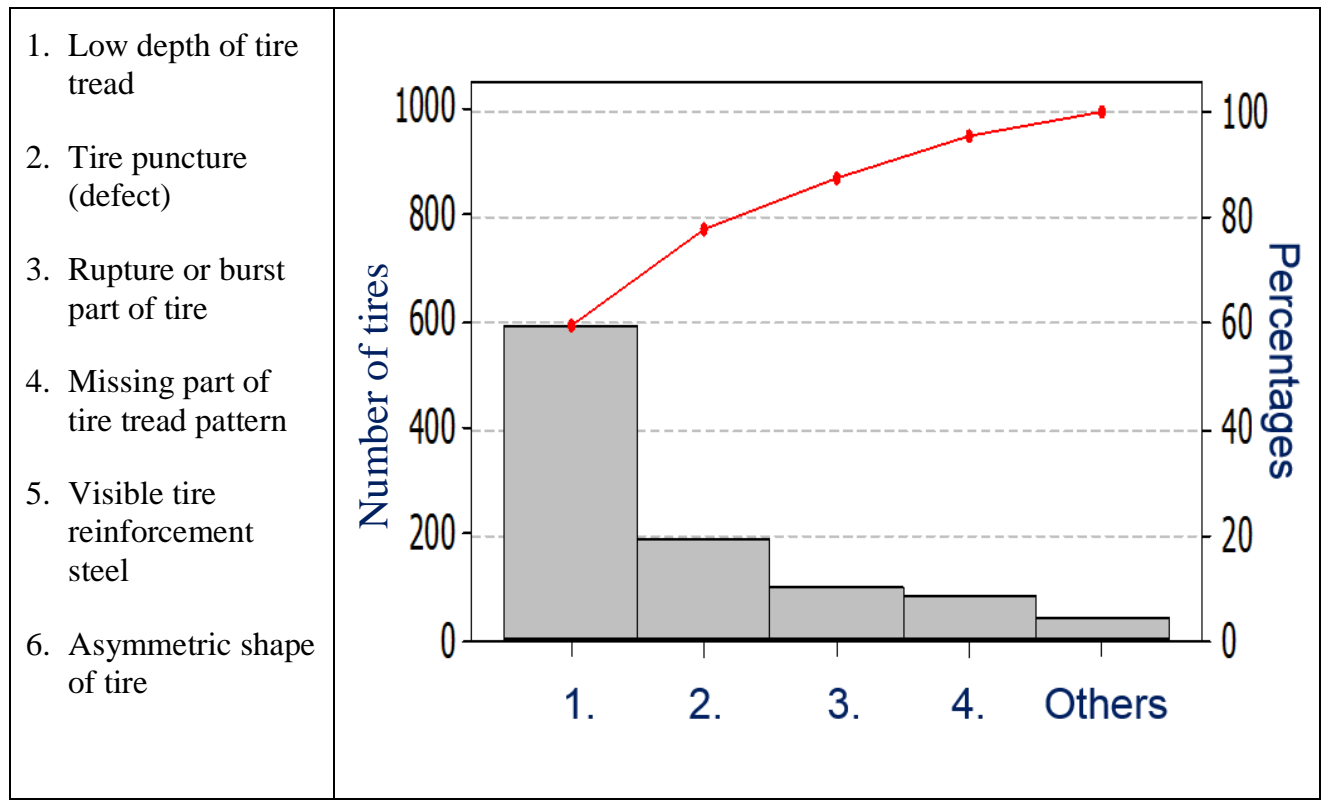

Figure 3 - Pareto analysis of tire rejection

According to results of Pareto analysis presented in Figure 3 the main reason causing $60 \%$ of tire rejection is low depth of tire tread. That is why the improvement team organize an brainstorming session, that focus on identification of causes of low depth of tire tread. For better understanding of issues, that can be tackled by improvement effort, found causes were categorized into four categories, which are presented in Table 1.

Table 1 - Categorization of causes of low depth of tire tread

\begin{tabular}{l|l|l|l}
\hline $\begin{array}{l}\text { Causes, which organisation can measure } \\
\text { and } \\
\text { cannot influence }\end{array}$ & $\begin{array}{l}\text { Causes, which } \\
\text { are hard to } \\
\text { measure for } \\
\text { organization, } \\
\text { but they can } \\
\text { be influenced }\end{array}$ & $\begin{array}{l}\text { Causes, } \\
\text { which } \\
\text { organization } \\
\text { don't want } \\
\text { to influence }\end{array}$ & $\begin{array}{l}\text { Causes, } \\
\text { which } \\
\text { organization } \\
\text { can measure } \\
\text { and can } \\
\text { influence }\end{array}$ \\
\hline \hline Weather & $\begin{array}{l}\text { Drivers } \\
\text { attention }\end{array}$ & Car brand & $\begin{array}{l}\text { Tire tread } \\
\text { type }\end{array}$ \\
\hline Traffic & $\begin{array}{l}\text { Process of tire } \\
\text { maintenance }\end{array}$ & $\begin{array}{l}\text { Number and } \\
\text { type of axle } \\
\text { trees }\end{array}$ & $\begin{array}{l}\text { Truck } \\
\text { geometry }\end{array}$ \\
\hline
\end{tabular}




\begin{tabular}{|c|c|c|c|}
\hline $\begin{array}{l}\text { Causes, which organisation can measure } \\
\text { and } \\
\text { cannot influence }\end{array}$ & $\begin{array}{l}\text { Causes, which } \\
\text { are hard to } \\
\text { measure for } \\
\text { organization, } \\
\text { but they can } \\
\text { be influenced }\end{array}$ & $\begin{array}{l}\text { Causes, } \\
\text { which } \\
\text { organization } \\
\text { don't want } \\
\text { to influence }\end{array}$ & $\begin{array}{l}\text { Causes, } \\
\text { which } \\
\text { organization } \\
\text { can measure } \\
\text { and can } \\
\text { influence }\end{array}$ \\
\hline Tire temperature & $\begin{array}{l}\text { Experience of } \\
\text { employee of } \\
\text { tire repair shop }\end{array}$ & $\begin{array}{l}\text { Type of truck } \\
\text { breaks }\end{array}$ & Tires brand \\
\hline Tire shape & $\begin{array}{l}\text { Cleanliness of } \\
\text { truck company } \\
\text { area }\end{array}$ & $\begin{array}{l}\text { Maximum } \\
\text { carrying } \\
\text { capacity }\end{array}$ & Tire inflation \\
\hline Truck lock-on & & $\begin{array}{l}\text { Type of } \\
\text { cargo }\end{array}$ & $\begin{array}{l}\text { Quality of } \\
\text { tire }\end{array}$ \\
\hline Type of road & & $\begin{array}{l}\text { Quality and } \\
\text { type of wheel } \\
\text { disk }\end{array}$ & $\begin{array}{l}\text { Tire location } \\
\text { in the truck }\end{array}$ \\
\hline Road surface & & $\begin{array}{l}\text { Speed of } \\
\text { truck }\end{array}$ & Wheel load \\
\hline Number of road holes & & $\begin{array}{l}\text { Length of } \\
\text { road }\end{array}$ & $\begin{array}{l}\text { Tire } \\
\text { installation } \\
\text { process }\end{array}$ \\
\hline Road quality & & $\begin{array}{l}\text { Safety of } \\
\text { driver and } \\
\text { cargo }\end{array}$ & $\begin{array}{l}\text { Structure of } \\
\text { route }\end{array}$ \\
\hline Road cleanliness & & $\begin{array}{l}\text { Road surface } \\
\text { of loading } \\
\text { and } \\
\text { unloading } \\
\text { site } \\
\end{array}$ & $\begin{array}{l}\text { Tires } \\
\text { material }\end{array}$ \\
\hline Breaking frequency & & & $\begin{array}{l}\text { Wheel disk } \\
\text { material }\end{array}$ \\
\hline Breaking intense & & & $\begin{array}{l}\text { Driving } \\
\text { technique of } \\
\text { drivers }\end{array}$ \\
\hline Truck breakaway & & & $\begin{array}{l}\text { Storage of } \\
\text { tires }\end{array}$ \\
\hline Road material & & & $\begin{array}{l}\text { Tires } \\
\text { dimension }\end{array}$ \\
\hline
\end{tabular}

\subsection{Screening experiment}

Screening experiment was next step of plan phase. Its aim was to roughly determine, which of identified suspicious factors should have impact on examined variable and therefore had to be fully investigated by full factorial DOE. Secondary objective of screening experiment was to test whether the route as well as measurement procedure are appropriate for full factorial experiment. The screening experiment examined 7 factors by 
conducting 8 trips from Kosice in Slovakia to Onesti in Romania. Seven selected factors and their levels are presented in Table 2.

Table 2 - Factors selected for screening experiment

\begin{tabular}{l|l|l|l}
\hline Factors & \multicolumn{2}{|c|}{ Levels } & \multicolumn{1}{|c}{ Variable } \\
\hline A. Driving technique & Non experienced driver & Experienced driver & Discrete \\
\hline B. Tire price & Expensive & Cheap tire & Discrete \\
\hline C. Tire inflation & $8 \mathrm{kPa}$ & $8,3 \mathrm{kPa}$ & Continuous \\
\hline D. Type of tire tread & Universal tread & Winter tread & Discrete \\
\hline E. Truck condition & New truck & Old truck & Discrete \\
\hline F. Truck type & Semi-automatic-trailer & Trailer & Discrete \\
\hline G. Length of tire storage & From storage & $\begin{array}{l}\text { Direct from } \\
\text { manufacturer }\end{array}$ & Discrete \\
\hline
\end{tabular}

Results from screening experiment verified, that selected route is sufficient for measuring decreasing depth of tire tread. Moreover the experiment helps to estimate four factors which could significantly influence depth of tire tread. Evaluation of experiment is presented in Table 3. Very rough estimate of factors' impact is presented in last column. Four mostly influential factors are driving technique, tire inflation, tire price, truck type. These factors were selected for full factorial design of experiment.

Table 3 - Results of screening experiment

\begin{tabular}{|c|c|c|c|c|c|}
\hline$x_{i}$ & levet & B: & $\mathrm{sin}_{1}$ & $E_{r}$ & $\left|E_{x \mid}\right|$ \\
\hline ntercept & & 0.255 & 0,000 & - & \\
\hline A & 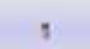 & 0.0250 & 0.000 & -0.0500 & \\
\hline B & 1 & 0.0150 & 0,000 & $-0,0900$ & $=$ \\
\hline c & 8.000 & 0.0400 & 0.000 & -0.0600 & \\
\hline D & 1 & $-0.00000000000 \mathrm{C}$ & 0.000 & 0.000000000000 & 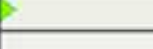 \\
\hline E & 1 & $-0,000000000000$ & 0,000 & 0.000500000000 & 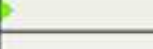 \\
\hline$F$ & 1 & 0,00500 & 0,000 & $-0,0100$ & $E$ \\
\hline G & 7 & $0,000000000000 \%$ & 0,000 & $-0,0000000000 \mathrm{C}$ & 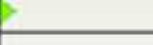 \\
\hline
\end{tabular}




\subsection{Full factorial DOE}

Last step of planning phase consist of creation of full factorial design, which can be implement during the "DO" phase. Screening experiment revealed four significant factors so improvement team decide for full factorial $2^{4}$ plan, which require 16 runs. Because chosen combination of route and transported material were frequent in the organization, use of full factorial design instead of fractional factorial design was preferred. In order to gain more precise results, the runs were randomized. English translation of final plan is presented in Table 4.

\subsection{Do}

The Do phase consist of execution of runs according to plan presented in Table 4. As was mentioned earlier, the tire tread worn out was measured as decrease in depth of tire's tread. The samples were collected from left and right leading tire of truck after the run. The gaps between runs were not similar. They depend on frequency of the orders.

\subsection{Check}

Check phase consists of evaluation of experiment and determination of factors which significantly influence the depth of tire tread and therefore tire deterioration process. It starts with evaluation of regression model presented in table 5 .

Table 4 -Plan of full factorial design

\begin{tabular}{|l|l|l|l|l|}
\hline run no. & A- Driving technique & B - Tire inflation & C - The price & D - Truck type \\
\hline 1 & experienced & 8.3 & expensive & trailer \\
\hline 2 & non-experienced & 8.3 & expensive & trailer \\
\hline 3 & non-experienced & 8.3 & cheap & semi-automatic trailer \\
\hline 5 & experienced & 8 & cheap & semi-automatic trailer \\
\hline 6 & non-experienced & 8 & cheap & semi-automatic trailer \\
\hline 7 & non-experienced & 8 & expensive & semi-automatic trailer \\
\hline 8 & experienced & 8.3 & expensive & semi-automatic trailer \\
\hline 9 & experienced & 8 & expensive & trailer \\
\hline 10 & non-experienced & 8.3 & cheap & trailer \\
\hline 11 & experienced & 8 & expensive & semi-automatic trailer \\
\hline 12 & experienced & 8 & cheap & trailer \\
\hline 13 & non-experienced & 8.3 & expensive & semi-automatic trailer \\
\hline 14 & experienced & 8.3 & cheap & semi-automatic trailer \\
\hline 15 & experienced & 8,3 & cheap & trailer \\
\hline & non-experienced & 8 & cheap & trailer \\
\hline
\end{tabular}


Table 5 -Evaluation of full factorial design

\begin{tabular}{|c|c|c|c|c|c|c|}
\hline$x_{1}$ & level & $b_{1}$ & $s_{0_{1}}$ & $t_{1}$ & $\left|t_{t}\right|$ & P \\
\hline Intercept & & 0.188 & 0.00256 & $73.424^{\star \star \star}$ & 21 & $<0.0001$ \\
\hline A & & 0.0159 & 0.00256 & $6.231^{\star \star \star}$ & \begin{tabular}{|c|c|} 
\\
\end{tabular} & $<0.0001$ \\
\hline B & & -0.0228 & 0.00256 & $-8.918^{\star \star \star}$ & & $<0.0001$ \\
\hline C & & -0.0109 & 0.00256 & $-4.276^{\star \star \star *}$ & \begin{tabular}{|l|l|} 
\\
\end{tabular} & 0.000579 \\
\hline D & & 0.000937 & 0.00256 & 0.367 & 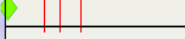 & 0.719 \\
\hline$A B$ & & 0.00281 & 0.00256 & 1.100 & & 0.288 \\
\hline$A C$ & & 0.00219 & 0.00256 & 0.855 & & 0.405 \\
\hline$A D$ & & 0.00156 & 0.00256 & 0.611 & D & 0.550 \\
\hline$B C$ & & -0.00281 & 0.00256 & -1.100 & & 0.288 \\
\hline$B D$ & & 0.000313 & 0.00256 & 0.122 & 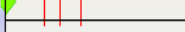 & 0.904 \\
\hline$C D$ & & 0.00469 & 0.00256 & 1.833 & & 0.0855 \\
\hline$A B C$ & & -0.00469 & 0.00256 & -1.833 & & 0.0855 \\
\hline ABD & & 0.000937 & 0.00256 & 0.367 & L & 0.719 \\
\hline$A C D$ & & -0.00219 & 0.00256 & -0.855 & & 0.405 \\
\hline$B C D$ & & -0.00219 & 0.00256 & -0.855 & & 0.405 \\
\hline$A B C D$ & & -0.00156 & 0.00256 & -0.611 & 2 & 0.550 \\
\hline
\end{tabular}

A: Driving technique, B: Tire inflation, C: Tire price, D: Truck type

According to the results, three of four factors, such as A: Driving technique, B: tire inflation and C: tire price have statistically significant $(\alpha=0,01)$ impact on depth of tires tread. On the other hand experiment didn't revealed any statistically significant interaction between factors. The influence of factors on tire tread worn-out $(\mathrm{mm})$ is presented by slope of the line in Figure 4 . The steeper line means higher impact. 


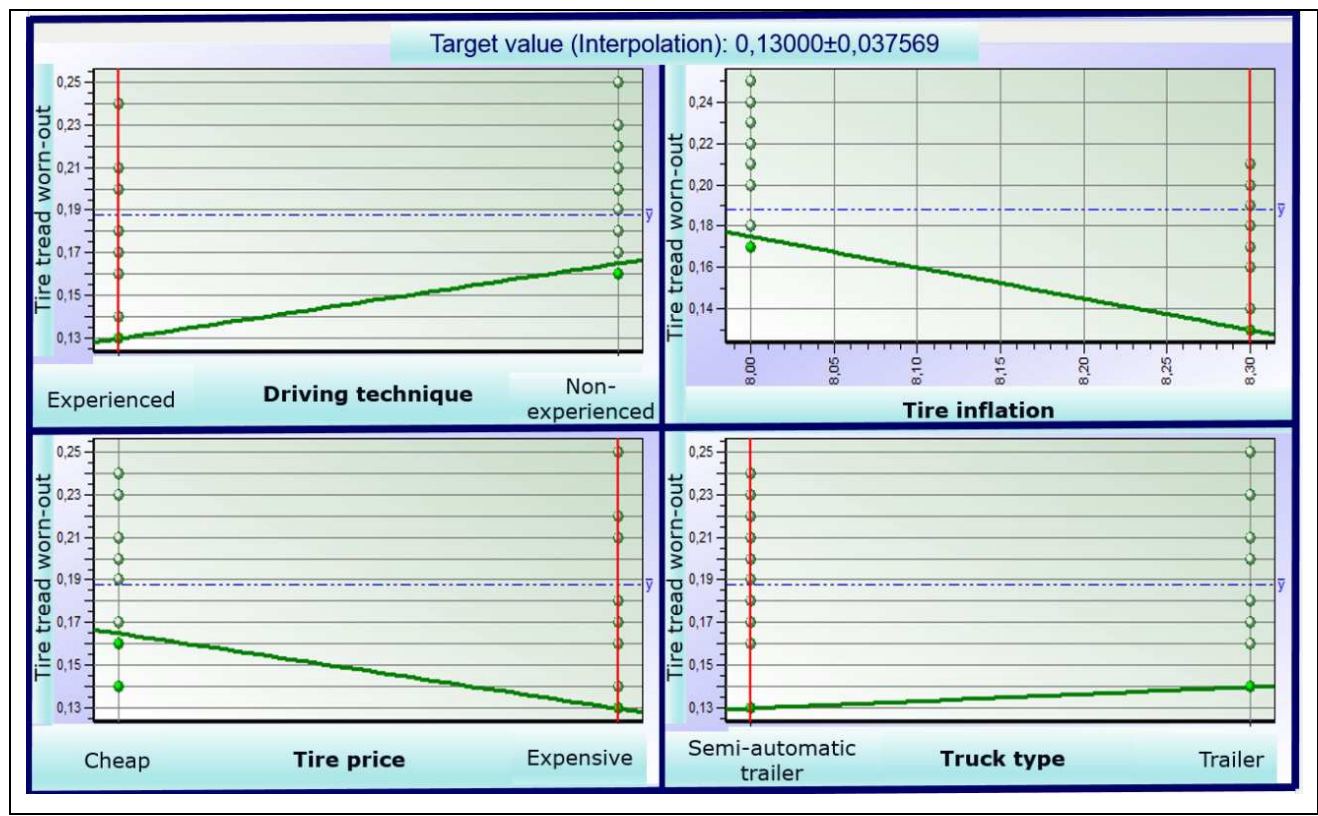

Figure 4-Overview of factors' influence

Based on previous two figures, it can be claim, that the tire inflation has from all examined factors most significant impact on depth of tires tread. Although the exact range of inflation cannot be publish, the rule: "the higher tire inflation, the lower tread worn-out" is valid. Second most significant factor is driving technique. According to the results if other researched parameters have their optimal values, it was estimated that experienced driver causes approximately $21 \%$ less tire tread worn-out, than non-experienced one. The last of identified factors is tire price. Based on our findings the tire price (as a very vague measure of tire quality), has also significant impact on depth of tire tread. Similar to previous factor, also in term of tire price it was estimated, that if other researched parameters have their optimal values, the changing from cheap tire to expensive one can save almost $20 \%$ of tire tread worn-out.

Final part of experiment evaluation consists of determination of optimal settings. The aim of optimizing task was to minimize tires tread worn-out, which will minimize the decrease of tires' tread depth, which should improve tires' deterioration process as well as their lifetime. Founded optimal settings are presented in the Figure 5. 


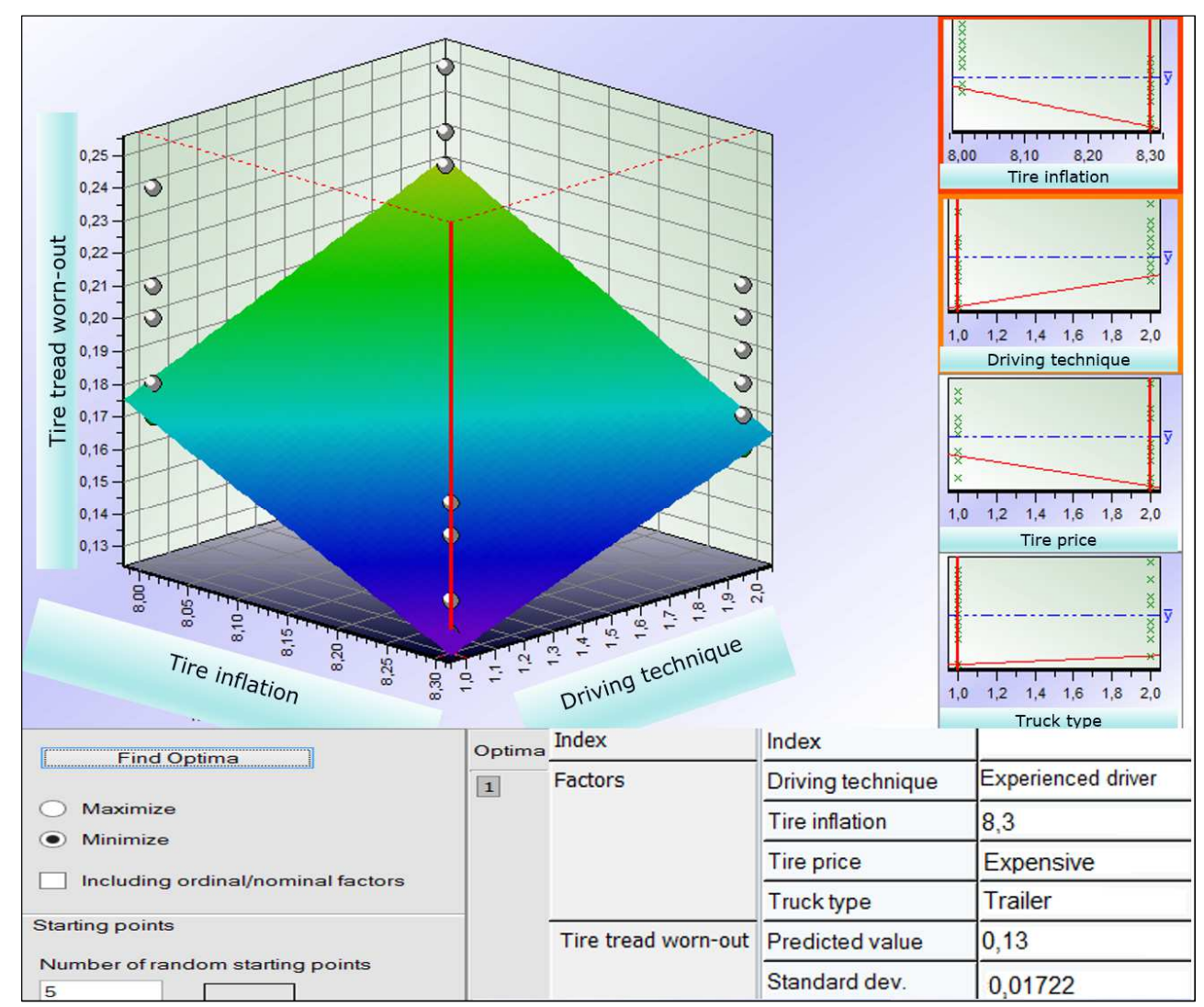

Figure 5 - Overview of optimal setting

\subsection{Action}

Action phase of improvement effort focus on formulation of corrective action based on results of experiment. First task was to implement actions, which can secure appropriate pressure in trucks' tires. Therefore organization establish system of tires' presure controls. These controls were executed by members of company's security service and conducted during refueling process. Every trucks with schleduled route longer than $1000 \mathrm{~km}$ had to be check before journey. For other trucks with schleduled shorter routes, organization create system of radom controls. Because every driver is responsible for its truck, insufficient tire pressure had effect on performance evaluation of the driver. According to another experiment conducted in truck company, driving technique is also main driver of fuel consumption. Therefore company decide that drivers with constantly excesive consumption of fuel as well as drivers with high consumption of tires must conduct draving lessons from driver with lowest average fuel consumption. In termo of tires organization decide to purchase expensive tires, unless the purchase price exceed $20 \%$ of tire from manufacturer of the cheap tires.

The final stage of action phase consists of collecting data, monitoring improvement, and prepare background for further efforts. 


\section{CONCLUSION}

Presented improvement effort is an typical example of low-cost experiment. Appart from sets of new tires, organization didn't have to buy any equipment or hire extra man power. The whole experiment were conducted from internal sources and organization doesn't recognized any extraordinary increase of costs during its length. Moreover, based on managed logistics none of internal processes had to be stopped or postpone during the experiment. Frequent delivery of goods chosen for experiment to destination chosen for experiment, enable use of full factorial design. Experiment identified three significant factors and led to implementation of four corrective actions, which doesn't require additional costs.

\section{REFERENCES}

Antony, J., Coleman, S., Montgomery, D. C., Anderson, M. J., and Silvestrini, R. T., 2011. Design of experiments for non-manufacturing processes: benefits, challenges and some examples. Proceedings of the Institution of Mechanical Engineers, Part B: Journal of Engineering Manufacture, http://dx.doi.org/10.1177/0954405411395857.

Barad, M., 2014. Design of Experiments (DOE)—A Valuable Multi-Purpose Methodology. Applied Mathematics, 5 pp. 2120-2129, http://dx.doi.org/10.4236/am.2014.514206.

Chompu-inwai, R., Jaimjit, B., and Premsuriyanunt, P., 2014. A combination of Material Flow Cost Accounting and design of experiments techniques in an SME: the case of a wood products manufacturing company in northern Thailand. Journal of Cleaner Production, Available through: http://dx.doi.org/10.1016/j.jclepro.2014.08.039.

Firka, D., 2011. Statistical, technical and sociological dimensions of design of experiments. The TQM Journal, 23(4) pp. 435-445.

Ilzarbe, L., 2008. Practical applications of design of experiments in the field of engineering: a bibliographical review. Quality and Reliability Engineering International, 24(4) pp. 417-28.

Johnson, L. A., Steele, J. C., 2012. Five key steps to successful design of experiments. Global Business and Organizational Excellence, 31(4), pp. 38-47.

Kleijnen, J. P., 2005. An overview of the design and analysis of simulation experiments for sensitivity analysis. European Journal of Operational Research, 164(2), pp. 287-300

Szabo, S., Ferencz, V., and Pucihar, A., 2013. Trust, Innovation and Prosperity. Quality Innovation Prosperity. 17 (2), pp. 1-8, DOI: 10.12776/qip.v17i2.224. 
Tanco, M., Viles, E., Ilzarbe, L., and Álvarez, M. J., 2008. How is experimentation carried out by companies? A survey of three European regions. Quality and Reliability Engineering International, 24(8) pp. 973-981.

\section{ABOUT AUTHORS}

Ing. Bibiana Kaselyova, PhD. student at Faculty of Mining, Ecology, Process Control and Geotechnologies at Technical University of Košice, e-mail: bibiana.kaselyova@tuke.sk

Ing. Michal Tkáč, PhD. Researcher at Faculty of Business Economics with seat in Košice of University of Economics Bratislava, e-mail: michal.tkac1@euke.sk 